R.S.E.W. Leuven, A.M.J. Ragas, A.J.M. Smits \& G. van der Velde (eds), Living Rivers: Trends and Challenges in Science and Management

DOI $10.1007 / \mathrm{s} 10750-005-1903-9$

\title{
BasinBox: a generic multimedia fate model for predicting the fate of chemicals in river catchments
}

\section{A. Hollander1,*, M.A.J. Huijbregts1, A.M.J. Ragas1 \& D. van de Meent1,2}

1Department of Environmental Science, Institute for Wetland and Water

Research, Radboud University Nijmegen, P.O. Box 9010, 6500 GL Nijmegen, The Netherlands

2National Institute of Public Health and the Environment, Laboratory for

Ecological Risk Assessment, P.O. Box 1, 3720 BA Bilthoven, The Netherlands

(*Author for correspondence: E-mail: a.hollander@science.ru.nl)

\begin{abstract}
Multimedia fate models have proven to be very useful tools in chemical risk assessment and management. This paper presents BasinBox, a newly developed steady-state generic multimedia fate model for evaluating risks of new and existing chemicals in river basins. The model concepts, as well as the intermedia processes quantified in the model, are outlined, and an overview of the required input parameters is given. To test the BasinBox model, calculations were carried out for predicting the fate of chemicals in the river Rhine basin. This was done for a set of 3175 hypothetical chemicals and three emission scenarios to air, river water and cropland soils. For each of these hypothetical chemicals and emission scenarios the concentration ratio between the downstream area and the upstream area was calculated for all compartments. From these calculations it appeared that BasinBox predicts significant concentration differences between upstream and downstream areas of the Rhine river basin for certain types of chemicals and emission scenarios. There is a clear trend of increasing chemical concentrations in downstream direction of the river basin. The calculations show that taking into account spatial variability between upstream, midstream and downstream areas of large river basins can be useful in the predictions of environmental concentrations by multimedia fate models.
\end{abstract}

\section{Introduction}

For more than 20 years now, multimedia fate models have been used for the prediction of chemical fate and exposure in the environment. Baughman \& Lassiter (1978) and Mackay \& Paterson (1981) first introduced this kind of models, the socalled 'fugacity models' or 'box models', in which the fate of chemicals in different environmental media was calculated based on physicalchemical properties of the compound, environmental characteristics and emission data. The first models, e.g. Mackay's unit world model (Mackay \& Paterson, 1981; Mackay et al., 1983), were relatively simple in structure and detail, but over time the models became more complex and sophisticated. Different types of compartments were added to the models, i.e. vegetation compartments (Trapp \& Matthies, 1996; Severinsen\&Jager, 1998; Cousins\&Mackay, 2001), and organic film-compartments coating impervious surfaces (Diamond et al., 2001). Nested, dynamic and GIS-based models were developed (Brandes et al., 1996; Woodfine et al., 2001; Suzuki et al., 2004), models with layered air and soil compartments 
arose (McKone, 1993; Toose et al., 2004), and models for multi-species chemicals were introduced (Fenner et al., 2000; Cahill \& Mackay, 2003).

Multimedia fate models have proven to be very useful tools in chemical risk assessment and management. Their multimedia character and relatively low complexity make them particularly useful to evaluate the fate of new and existing chemicals. In the European Union the EUSES model (Vermeire et al., 1997; Vermeire et al., 2005) is currently being used for risk assessment and management purposes, while in the USA, the Total Risk Integrated Methodology (TRIM.FaTE; US-EPA, 2002) is typically applied. Most multimedia fate models used in the risk assessment of chemicals are based on a geo-political parameterization, e.g. per country or province, and originate from a generic environmental approach, as for example described in the EU Technical Guidance Documents (ECB, 2003). For water quality management purposes in the European Union, however, the regulatory concept is shifting more and more towards an environmentally specific approach.

This regulatory concept is described in the European Water Framework Directive (EC, 2000), in which the European Union defined ecological and chemical water standards at a catchment scale. This catchment approach could also be very advantageous for the risk assessment policy of new and existing chemicals, since river basins form more clearly defined physical entities than political regions. Except for air-borne transport, transport of chemicals occurs only within the basin, which facilitates the description of transport flows in the model. Moreover, in the case of river basin modelling, floodplain areas, which are being regarded as valuable areas for nature conservation, can be modelled separately. It will therefore be useful to implement the concept of catchment based modeling in the process of risk management of chemicals.

Very few multimedia fate models have been developed using river catchments as the basic environmental unit, since chemical modelling in catchments usually focuses on in-stream water quality only. This, for example, is the case in the Great-ER model (Feijtel et al., 1997) and the LOIS model (Boorman, 2003). Coulibaly et al. (2004) did develop a multimedia catchment model for the Passaic River Watershed in the USA, and Suzuki et al. (2004) described a multimedia model built up from 38,000 river catchments in Japan (G-CIEMS), but both are very site-specific GIS-based models of relatively small basins (up to $200 \mathrm{~km} 2$ ) that cannot be easily applied to other river catchments.

The goal of this study is to develop a generic steady-state multimedia fate model to evaluate risks of new and existing chemicals in river basins. Here, this model, called BasinBox, is presented. The model concept, as well as the environmental processes considered in the model are outlined, and an overview of the required input parameters is given. Furthermore, the model is applied in a case study on the river Rhine basin area for a set of 3175 hypothetical chemicals, representing the whole range of chemical property combinations, to test whether the catchment approach applied in BasinBox yields valuable insights in the context of multimedia fate modelling. For that purpose, concentration ratios between the upstream area and the downstream area are analysed for various compartments and emission scenarios. 


\section{Materials and methods}

\section{Model description}

In the BasinBox model, the river basin is subdivided into an upstream, midstream and downstream area, following Schumm's (1977) idealized scheme of a river basin consisting of three zones arranged in downstream sequence. Since many environmental parameters and process intensities vary between the different zones of a river basin, this subdivision allows the modeller to incorporate basic spatial variability into the model. The model areas are interconnected by singledirection river flows and two-direction air flows. Figure 1 a gives a schematic representation of the three sequential areas and the connections between these areas.

Each of the upstream, midstream and downstream areas consists of 21 compartments, representing different environmental media. Nine of these compartments belong to the floodplain zone and 11 compartments belong to the catchment zone. One single air compartment covers both the floodplain and the catchment zone. The floodplain zone is defined as the area of the river basin that consists of the river or its main tributaries and the land that is being flooded temporally each year. We chose to make the distinction between the floodplain and the catchment zone since some processes, like sedimentation and groundwater flow, proceed differently in these two zones. Moreover, floodplain areas are regarded as valuable habitats for nature conservation and development (Nienhuis et al., 2002; ECNC, 2004; De Nooij et al., 2006). In the floodplain zone, a river and a sediment compartment, three unsaturated soil compartments (pasture-, cropland- and natural soil), saturated soil, and three vegetation compartments (pasture-, cropland-, and natural vegetation) have been distinguished. In the catchment zone one can find compartments for primary waters, secondary/tertiary waters and sediment, three unsaturated soil compartments (pasture-, cropland- and other soil), saturated soil, and three vegetation compartments (pasture-, cropland-, and natural vegetation). A schematic representation of the compartmental construction and the transport routes between the compartments is given in Figure $1 \mathrm{~b}$.

The concentrations calculated by BasinBox are affected by emissions, degradation processes and processes that cause chemical mass flows to and from the compartments. Mass balance equations can be written for all compartments, having the following general format:

$$
\begin{aligned}
V_{i} * \frac{\partial C_{i}}{\partial t}= & \text { Emission }_{i}+\text { Import }_{i}-\text { Export }_{i} \\
& - \text { Degradation }_{i}+\text { Advection }_{i j} \\
& + \text { Diffusion }_{i j}
\end{aligned}
$$

with Vi being the volume of compartment i (m3) and $\mathrm{Ci}$ being the chemical concentration in that compartment ( $\mathrm{mol} \mathrm{m}) 3$ ). Emissioni, and Degradationi represent emission to, and degradation from compartment $i$, respectively. Importi is the mass flow to compartment i from outside the basin area, while Exporti stands for the mass flow from I out of the basin area. Advectionij and Diffusionij are the gross advective and diffusive mass flows between compartments $i$ and $j$ within the river basin. At steady state, the mass flows balance. The set of mass balances is solved using a matrix inversion routine. BasinBox calculates concentrations of chemicals in each of the compartments, using Microsoft Excel software in combination with the Poptools-extension (CSIRO, 1994). 

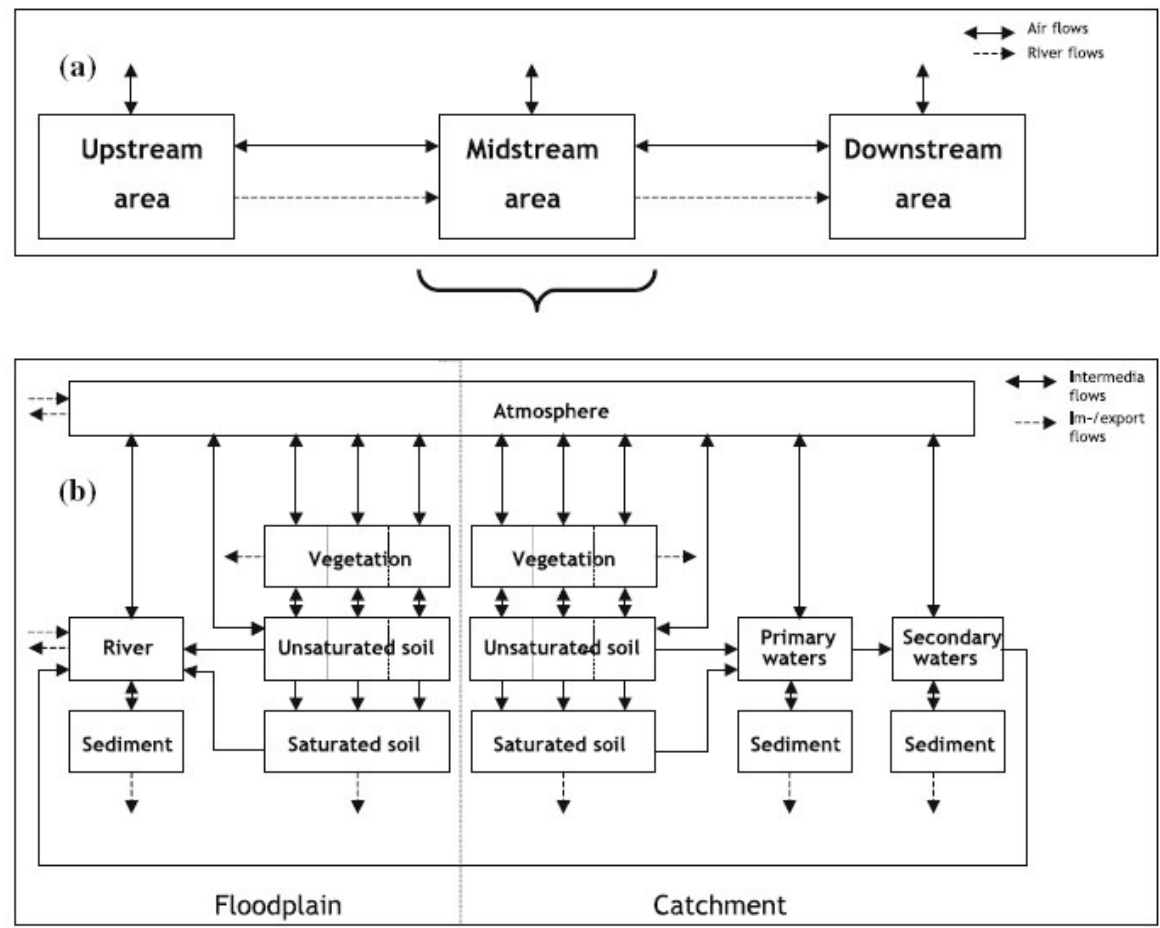

Figure 1. Schematic representation of the BasinBox model. (a) Schematic representation of the three sequential areas (up-, mid- and downstream) and the connections between these areas. (b) Schematic representation of the compartmental construction and the transport routes between the compartments.

Since BasinBox is a steady state model, it is assumed that the environmental properties of and emissions to the compartments do not change over time. It is also assumed that equilibrium exists between the different phases within each compartment (e.g. gas, water and solids in soil). Moreover, each compartment is assumed to be completely mixed, which implies that all environmental properties and concentrations are equal throughout a compartment. Exceptions to this are the unsaturated soil compartments, where depthdependent concentration differences in soil can significantly affect substance flows (e.g. volatilisation, leaching) throughout the soil profile. To overcome this problem, the theoretical principle of exponentially declining soil concentrations with depth of McKone \& Bennett (2003), as implemented in multimedia models by Hollander et al. (2004), was introduced in the BasinBox model. This method applies correction factors that account for the deviation of depth-dependent soil concentrations from depthaveraged concentrations.

\section{Model processes}

All intermedia mass flows affecting the concentration of a chemical in a compartment (in mol s)1) can be described as the product of a transport coefficient (in $\mathrm{m} 3 \mathrm{~s}$ )1) and the concentration (in mol m)3) in the compartment from which the mass flow originates. The transport coefficient is calculated as the product of a mass transfer coefficient (in $\mathrm{m} \mathrm{s}$ )1) and the interfacial area (in m2). We distinguish diffusive and advective mass flows and transport coefficients. A diffusive mass flow is treated as a process driven by differences in the chemical potentials in the two media. Advective mass flows proceed by a carrier that physically flows from one compartment to another, e.g. by air or water. The amount of advective mass transport depends on the rate of the carrier flow and the concentration of the compound in the carrier. 


\section{Air and water transport flows}

In the BasinBox model, air and water are regarded as the main carriers for advective mass flows. Air transport within the modelled river basin as well as into and out of it is dependent on the wind direction and the geometric orientation of the areas in the river basin, e.g. the position of the upstream area with regard to the midstream area, and the position of the midstream area with regard to the downstream area.

To calculate the source of imported air, and subsequently, the chemical concentration in the air imported to the area, for each of the possible combinations of wind directions and orientations of the river basin, an air-inflow scenario was formulated for the upstream, midstream and downstream area. This generic calculation method enables the user to enter all possible orientations of a river basin to calculate the source of airflows into and out of the upstream, midstream and downstream area. As constant atmospheric pressure is assumed, the amount of imported air equals the amount of exported air. This amount is estimated based on the residence time of air in the upstream, midstream and downstream area, calculated using the annual average wind speed, the distance across the area in each of the eight compass directions, and the frequencies of wind directions, following the method described by Webster et al. (2004).

(a)

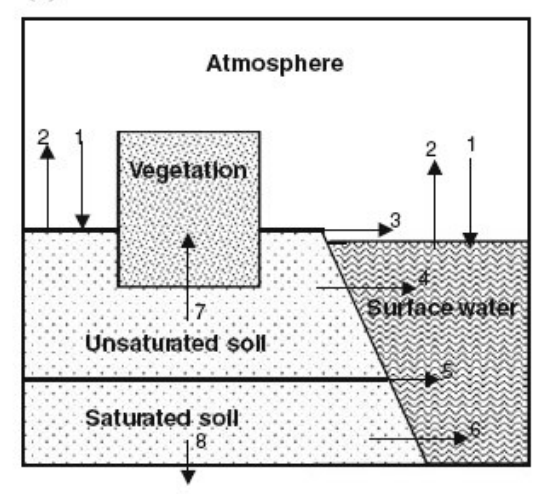

(b)

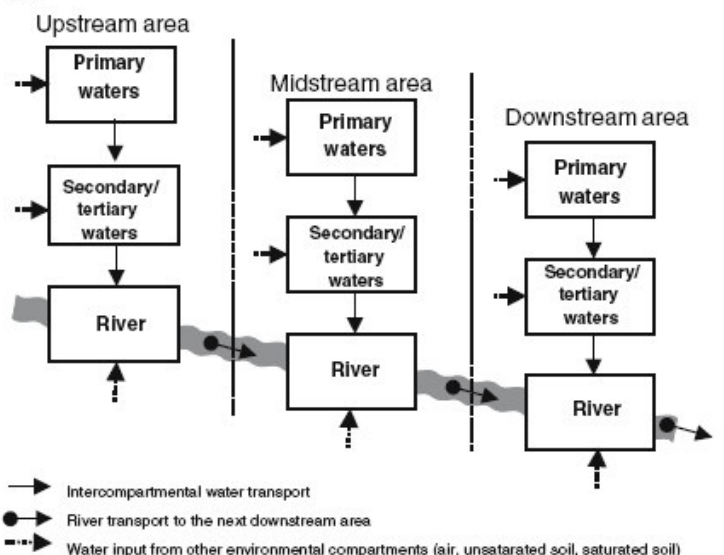

Figure 2. Schematic representation of the water balance elements of BasinBox. (a) Water flows between the air, soil, surface water and vegetation compartments. $1=$ rain input (to soil and water), $2=$ evaporation, $3=$ surface runoff, $4=$ subsurface runoff, 5 = tube drainage, 6 = groundwater drainage, $7=$ transpiration, $8=$ groundwater discharge to deeper aquifers. (b) Water flows between the different surface water compartments.

Since there is no water flow over the borders of a river catchment, it is possible to accurately construct a water balance, describing all relevant water transport processes within a river basin (Fig. 2). Figure 2a shows the water transport routes between air and soil, air and water, soil and water and soil and vegetation. Water enters the model as precipitation, of which a certain fraction evaporates. A fraction of the water runs off over the soil surface to one of the surface water compartments. Another fraction is discharged as subsurface flow at the mechanical reworking depth, and a third fraction is drained by tube drainage (except in natural soils where no tube drainage is assumed). The remaining water percolates to the saturated soil compartments. In the catchment zone of the model, it is assumed that a certain amount of groundwater is exported from the saturated soil zone to deeper aquifers and thus exported from the system. The remainder is transported from the saturated soil zone to the surface water compartments. In the floodplain zone all groundwater is assumed to recharge to the surface water compartment, since no groundwater export takes place at a 
location so close to the drainage base of the system. Figure $2 b$ shows the water transport routes between the different surface water compartments. The primary water compartments (ditches, pools) of the up-, mid- and downstream areas discharge to the secondary and tertiary water compartments (canals, brooks, small rivers) of these areas and those again discharge to their river water compartments. In the river compartments, water is being discharged in a downstream direction. A constant volume of the surface water compartment is assumed; this means that all surplus water is being transported following the routes described in Figure $2 \mathrm{~b}$. From the downstream area river compartment, water is exported from the system at the river mouth.

\section{Intermedia chemical transport processes}

\section{Air-surface area exchange}

Advective air-unsaturated soil and air-water transport occurs by wet and dry deposition. For the calculation of the dry deposition chemical mass flow, the dry deposition velocity of aerosol particles and the fraction of chemicals associated with aerosol in the atmosphere are used (Brandes et al., 1996). An interception fraction for dry aerosol interception by vegetation is introduced. Wet deposition is divided into gas washout and aerosol washout processes, both dependent on rain intensity and the fraction of gas and aerosols in the atmosphere. Gas washout is calculated using the dimensionless air-water partition coefficient (Den Hollander \& Van de Meent, 2004), while aerosol washout is calculated based on the aerosol collection efficiency (Mackay, 1991). For aerosol washout an interception fraction for vegetation is inserted. It is assumed that vegetation causes no interception in the case of gas washout.

Diffusive air-water, air-soil and air-vegetation transport occurs by gas absorption and volatilisation. These processes are calculated using the classic two-film resistance model (Schwarzenbach et al., 1993). For the soil-air mass flows a correction factor accounting for the deviation of the concentration at the top of the soil compartment from the average soil concentration (Hollander et al., 2004) is inserted. Diffusive air to vegetation transport vice versa is estimated from the overall mass transfer coefficient at the air-plant interface for natural and agricultural vegetation, following the description of Severinsen \& Jager (1998).

Water-sediment exchange and sediment burial Advective transport between the water and the sediment compartments occurs by sedimentation and resuspension. Gross sedimentation rates are calculated from the settling velocity of suspended particles and the concentration of suspended matter in the water compartments following the method of Brandes et al. (1996). Net sedimentation rates in the up-, mid- and downstream areas were derived from literature (Schwarzenbach et al., 1993; Trapp, 1996; Hofstee \& Leenaers, 2002).

Resuspension rates equal the difference between the gross sedimentation rates and the net sedimentation rates. Diffusive exchange proceeds by adsorption and desorption processes, based on the partial mass transfer coefficients at the water and the sediment side of the water-sediment interface. In the BasinBox model, the sediment compartments are modelled with a fixed depth. Therefore, a sediment burial flow is introduced, the burial mass transfer coefficient being equal to the product of the net sedimentation rate and the interfacial area. Unsaturated soil-vegetation exchange Chemical transport from unsaturated soil to vegetation proceeds by an advective transpiration flow. Severinsen \& Jager (1998) described the method used here, using a transpiration stream concentration factor (Briggs et al., 1982). Litter flow causes chemical transport from the vegetation compartments to the unsaturated soil compartments, of which the amount is 
derived from the growth rate of vegetation, and the harvesting efficiency (Severinsen \& Jager, 1998).

\section{Unsaturated soil-saturated soil-surface water exchange}

Several advective water-bound soil to water processes are modelled. On agricultural pasture and cropland soils, one water flow occurs at the soil surface (surface runoff), one at the mechanical reworking depth (subsurface flow), and one at the typical depth of drainage tubes (tube drainage). For natural soils, only surface runoff and subsurface flow processes are modelled. The principle of depth-dependent chemical concentrations is used for calculating the amount of chemicals involved in the different processes. For the surface runoff calculation, both the process of solute transport in runoff water and erosion (Asselman, 1997) are modelled.

The fraction of precipitation that does not flow from the unsaturated soil compartments to the surface water compartments percolates to the saturated soil zone. The chemical amount that is transported from the saturated soil zone to deeper aquifers is determined by an export fraction derived from literature (De Wit, 1999), the remainder is recharged to the surface water compartments.

\section{Degradation}

All chemical degradation is assumed to obey (pseudo) first order kinetics, following from a degradation rate constant, the volume of the compartment and the concentration. Following the method of Den Hollander \& Van de Meent (2004), the degradation rate constant in air is estimated from the fraction of the chemical in air that is associated with aerosol particles, and the $\mathrm{OH}$-radical concentration in air. Values for the degradation rate constants in water, sediments and soils are calculated using the degradation rate constant in the dissolved phase, the bulk degradation rate constant in sediments and in soils respectively, corrected for the actual temperature. The chemical degradation constants in vegetation are assumed to be ten times higher than those in soil (Brandes et al., 1996).

\section{Model parameterization}

The input for BasinBox consists of physical- chemical properties of the compound studied, environmental characteristics and emission data, the latter two being user-defined. Required physical- chemical properties of the compound are its molecular weight, octanol-water partition coefficient (Kow), vapour pressure, solubility, melting point, and degradation rate constants for bulk sediment, bulk soil, and the gas phase. The vapour pressure, the solubility and the degradation rates of a chemical are modelled as temperature dependent variables. Using the physical-chemical data the model estimates intermedia partition coefficients. The air-water partition coefficient (Kaw) is estimated from the ratio of the vapour pressure and the water solubility of the compound. The air-aerosol partitioning is determined on the basis of the chemical's vapour pressure, according to Junge (1977). The solids-water partition coefficient is calculated based on the relationship with Kow and the organic carbon content of the soil proposed by DiToro et al. (1991). The bioconcentration factor is estimated from the Kow and the fat content of the biota. For vegetation, the concentration ratio between plant tissue and water in thermodynamic equilibrium is estimated from the water and lipid contents of the plant tissue (Severinsen \& Jager, 1998).

Values for the environmental parameters and the emission rates are, dependent on the model scenario, to be defined by the user. The environmental parameters 
that need to be entered in the BasinBox model are listed in Table 1. Emissions in the model can take place to the air compartment, the water compartments and the different soil compartments.

\section{Case study for the river Rhine basin}

\section{Model area}

To test the BasinBox model, example calculations were carried out for predicting the fate of chemicals in the river Rhine basin. Environmental input parameters for BasinBox were collected for the upstream, midstream, and downstream areas of the Rhine basin (Table 1). The geometrical orientation of the upstream area with regard to the midstream area of the Rhine basin is South, while the orientation of the midstream area with regard to the downstream area is Southeast. Based on this orientation, together with information on the percentages of wind flowing in from the different compass directions, the chemical concentration in the inflowing air in the different areas of the river Rhine basin was calculated (Fig. 3). Figure 3a and Table 1 show the percentage of wind directions occurring in the river Rhine basin. For each of thewind directions, the model estimates the fraction of inflowing air occurring from outside the river basin as well as the fraction of inflowing air taking place from the other areas within the basin. Figure $3 \mathrm{~b}$ shows the total amounts of inflowing and outflowing air in the different areas of the Rhine basin, calculated using the wind directions of Figure $3 a$ and the residence times of air in the different areas.

In BasinBox it is possible to model periodical inundations of the floodplain zone of the river basin. For the Rhine basin, a yearly inundation of four weeks is assumed in the downstream area of the basin (Hofstee \& Leenaers, 2002). During this period gross and net sedimentation rates from the river water to the inundated floodplain soil are assumed to equal those rates from the river water to the sediment compartment. For the upstream and midstream areas of the Rhine basin, no periodical flooding was assumed in this case study. Set of hypothetical chemicals For the example calculations, a set of 3175 hypothetical chemicals was used, covering the entire space of plausible chemical partitioning properties and half-lives. The advantage of using this set instead of real chemical data is that even a set of hundreds of real chemicals does not densely cover the space of possible chemical property combinations (Fenner et al., 2005). The set of hypothetical chemicals used here includes all possible combinations of integer values of $\log$ Kaw from ) 11 to 2 and $\log$ Kow from ) 1 to 8 with the restriction that $-1 £(\log K o w-\log K a w) £ 15$ (Fenner et al., 2005). For the degradation halflives, all possible combinations of half-lives in air of $4,24,168,1000$, and $8760 \mathrm{~h}$ with half-lives in water of $24,168,1000,8760$ and $87,600 \mathrm{~h}$ were used. The halflife in soil and in sediment was set to twice the half-life in water, in order to limit the chemical properties that were varied to four (Stroebe et al., 2004).

\section{Emission scenarios}

With the whole set of hypothetical chemicals, the BasinBox model was run for three emissions, towards air, river water and cropland soils. Emission input towards air and river water was estimated using population density numbers, following Prevedouros et al. (2004). This method assumes that chemicals emitted to air and river water are mainly released from densely populated urban areas. Based on population density numbers in the Rhine basin area (Table 1), air and river water emissions take place in a ratio of 1:1.2:2 between the upstream, midstream and downstream areas (Nationmaster, 2005). Diffuse emissions to cropland soils will typically be pesticides, so input to cropland soils was estimated based on differences in cropland area between the upstream, midstream and 
Hydrobiologia (2006) 565:21-38

Table 1. Environmental input parameters for the BasinBox model in the case study for the river Rhine catchment

\begin{tabular}{|c|c|c|c|c|c|}
\hline Environmental parameter & Unit & $\begin{array}{l}\text { Value } \\
\text { upstream }\end{array}$ & $\begin{array}{l}\text { Value } \\
\text { midstream }\end{array}$ & $\begin{array}{l}\text { Value } \\
\text { downstream }\end{array}$ & Referenos \\
\hline Total area & {$\left[\mathrm{m}^{2}\right]$} & $6.17 \mathrm{E}+10$ & $6.17 \mathrm{E}+10$ & $6.17 \mathrm{E}+10$ & - \\
\hline Area fraction river & {$[-]$} & $1.00 \mathrm{E}-0.3$ & $1.62 \mathrm{E}-0.3$ & $1.88 \mathrm{E}-0.3$ & a \\
\hline Area fraction pasture soil fioodplain & {$[-]$} & $1.52 \mathrm{E}-0.3$ & $1.29 \mathrm{E}-03$ & $2.15 \mathrm{E}-0.3$ & a \\
\hline Area fraction cropland soil fioodplain & {$[-]$} & $4.40 \mathrm{E}-04$ & $1.38 \mathrm{E}-0.3$ & $1.05 \mathrm{E}-0.03$ & a \\
\hline Area fraction other soil foodplain & {$[-]$} & $2.05 \mathrm{E}-03$ & $1.64 \mathrm{E}-03$ & $5.65 \mathrm{E}-04$ & a \\
\hline Area fraction pasture soil catchment & {$[-]$} & $3.64 \mathrm{E}-01$ & $2.92 \mathrm{E}-01$ & $4.68 \mathrm{E}-01$ & a \\
\hline Area fraction cropland soil catchment & {$[-]$} & $1.06 \mathrm{E}-01$ & $3.12 \mathrm{E}-03$ & $2.30 \mathrm{E}-01$ & a \\
\hline Area fraction other soil catchment & {$[-]$} & $4.89 \mathrm{E}-01$ & $3.70 \mathrm{E}-03$ & $1.23 \mathrm{E}-01$ & a \\
\hline Area fraction primary waters catchment & {$[-]$} & $2.59 \mathrm{E}-02$ & $4.72 \mathrm{E}-04$ & $8.71 \mathrm{E}-02$ & a \\
\hline Area fraction secondary waters catchment & {$[-]$} & $1.00 \mathrm{E}-02$ & $1.99 \mathrm{E}-02$ & $8.71 \mathrm{E}-02$ & a \\
\hline Mixed height air compartment & {$[\mathrm{m}]$} & $1.00 \mathrm{E}+03$ & $1.00 \mathrm{E}+03$ & $1.00 \mathrm{E}+03$ & $\mathrm{~b}$ \\
\hline Depth river compartment & {$[\mathrm{m}]$} & $3.00 \mathrm{E}+00$ & $3.00 \mathrm{E}+\infty 0$ & $5.00 \mathrm{E}+\infty 0$ & c \\
\hline Depth sodiment compartments & {$[\mathrm{m}]$} & $3.00 \mathrm{E}-0.3$ & $3.00 \mathrm{E}-03$ & $3.00 \mathrm{E}-03$ & b \\
\hline Depth primary waters compartment & {$[\mathrm{m}]$} & $1 .(00 \mathrm{E}+\infty)$ & $1 .(0) \mathrm{E}+(0)$ & $1.00 \mathrm{E}+\infty 0$ & d \\
\hline Depth secondary waters compartment & {$[\mathrm{m}]$} & $2.00 \mathrm{E}+\infty 0$ & $2.00 \mathrm{E}+\infty 0$ & $2.00 \mathrm{E}+\infty 0$ & - \\
\hline Depth unsaturated soil compartments & {$[\mathrm{m}]$} & $1.00 \mathrm{E}+\infty 0$ & $1.00 \mathrm{E}+(0)$ & $1 .(0) \mathrm{E}+(0)$ & c \\
\hline Depth saturated soil compartments & {$[\mathrm{m}]$} & $2.00 \mathrm{E}+(0)$ & $2.00 \mathrm{E}+(00$ & $2.00 \mathrm{E}+00$ & - \\
\hline Solid phasc advection velocity soil & {$\left[\mathrm{m} \mathrm{s}^{-1}\right]$} & $6.34 \mathrm{E}-12$ & $6.34 \mathrm{E}-12$ & $6.34 \mathrm{E}-12$ & b \\
\hline Solid phase turbation coefficient soil & {$\left[\mathrm{m} \mathrm{s}^{-1}\right]$} & $6.37 \mathrm{E}-12$ & $6.37 \mathrm{E}-12$ & $6.37 \mathrm{E}-12$ & $\mathrm{~b}$ \\
\hline Volume fraction solids soil & {$[-]$} & $6.00 \mathrm{E}-01$ & $6.00 \mathrm{E}-01$ & $6.00 \mathrm{E}-01$ & - \\
\hline Volume fraction water unsaturated soil & {$[-]$} & $2.00 \mathrm{E}-01$ & $2.00 \mathrm{E}-01$ & $2.00 \mathrm{E}-01$ & - \\
\hline Volume fraction air unsaturated soil & {$[-]$} & $2.00 \mathrm{E}-01$ & $2.00 \mathrm{E}-01$ & $2.00 \mathrm{E}-01$ & - \\
\hline Volume fraction water saturated soil & {$[-]$} & $4.00 \mathrm{E}-01$ & $4.00 \mathrm{E}-01$ & $4 .(00 \mathrm{E}-01$ & - \\
\hline Volume fraction water sediment & {$[-]$} & $8 .(0) \mathrm{E}-01$ & $8.00 \mathrm{E}-01$ & $8.00 \mathrm{E}-01$ & f \\
\hline Volume fraction solids sediment & {$[-]$} & $2.00 \mathrm{E}-01$ & $2.00 \mathrm{E}-01$ & $2 .(0) \mathrm{E}-01$ & f \\
\hline Volume fraction water vegetation & {$[-]$} & $8.00 \mathrm{E}-01$ & $8.00 \mathrm{E}-01$ & $8.00 \mathrm{E}-01$ & b \\
\hline Mas fraction lipids vegetation & {$[-]$} & $1.50 \mathrm{E}-02$ & $1.50 \mathrm{E}-02$ & $1.50 \mathrm{E}-02$ & $\mathrm{~b}$ \\
\hline Leaf area index pasture vegetation & {$\left[\mathrm{m}^{2} \mathrm{~m}^{-2}\right]$} & $5.06 \mathrm{E}+00$ & $5.06 \mathrm{E}+(0)$ & $5.06 \mathrm{E}+00$ & $\mathrm{~g}$ \\
\hline Leaf area index cropland vegetation & {$\left[\mathrm{m}^{2} \mathrm{~m}^{-2}\right]$} & $1.71 \mathrm{E}+\infty 0$ & $1.71 \mathrm{E}+\infty 0$ & $1.71 \mathrm{E}+\infty 0$ & g \\
\hline Leaf area index natural vegetation & {$\left[\mathrm{m}^{2} \mathrm{~m}^{-2}\right]$} & $3.62 \mathrm{E}+\infty 0$ & $3.62 \mathrm{E}+(0)$ & $3.62 \mathrm{E}+\infty 0$ & g \\
\hline Vegetation cover pasture vegetation & {$[-]$} & $7.10 \mathrm{E}-01$ & $7.10 \mathrm{E}-01$ & $7.10 \mathrm{E}-01$ & $\mathrm{~h}$ \\
\hline Vegetation cover cropland vegetation & {$[-]$} & $8.60 \mathrm{E}-01$ & $8.60 \mathrm{E}-01$ & $8.60 \mathrm{E}-01$ & $\mathrm{~h}$ \\
\hline Vegetation cover natural vegetation & {$[-]$} & $9.00 \mathrm{E}-01$ & $9.00 \mathrm{E}-01$ & $9.00 \mathrm{E}-01$ & $\mathrm{~h}$ \\
\hline Vegetation mass pasture vegetation & {$\left[\mathrm{kg} \mathrm{m}^{-2}\right]$} & $1.20 \mathrm{E}+\infty 0$ & $1.20 \mathrm{E}+\infty 0$ & $1.20 \mathrm{E}+00$ & $\mathrm{i}$ \\
\hline Vegetation mass cropland vegetation & {$\left[\mathrm{kg} \mathrm{m}^{-2}\right]$} & $1.80 \mathrm{E}+00$ & $1.80 \mathrm{E}+00$ & $1.80 \mathrm{E}+00$ & $\mathrm{i}$ \\
\hline Vegetation mass other vegetation & {$\left[\mathrm{kg} \mathrm{m}^{-2}\right]$} & $2.40 \mathrm{E}+\infty 0$ & $2.40 \mathrm{E}+(0)$ & $2.40 \mathrm{E}+\infty 0$ & $\mathrm{i}$ \\
\hline Wet density of vegetation & {$\left[\mathrm{kg} \mathrm{m}^{-3}\right]$} & $9.00 \mathrm{E}+02$ & $9.00 \mathrm{E}+102$ & $9.00 \mathrm{E}+02$ & $\mathrm{i}$ \\
\hline Average wind speed & {$\left[\mathrm{m} \mathrm{s}^{-1}\right]$} & $2.90 \mathrm{E}+(00$ & $2.90 \mathrm{E}+(0)$ & $2.90 \mathrm{E}+(0)$ & j \\
\hline Fraction of wind from direction north & {$[-]$} & $9.00 \mathrm{E}-02$ & $9.00 \mathrm{E}-02$ & $9.00 \mathrm{E}-02$ & j \\
\hline Fraction of wind from direction north-east & {$[-]$} & $1.00 \mathrm{E}-01$ & $1.00 \mathrm{E}-01$ & $1.00 \mathrm{E}-01$ & j \\
\hline Fraction of wind from direction south-east & {$[-]$} & $1.20 \mathrm{E}-01$ & $1.20 \mathrm{E}-01$ & $1.20 \mathrm{E}-01$ & j \\
\hline Fraction of wind from direction south & {$[-]$} & $1.50 \mathrm{E}-01$ & $1.50 \mathrm{E}-01$ & $1.50 \mathrm{E}-01$ & j \\
\hline Fraction of wind from direction south-west & {$[-]$} & $2.00 \mathrm{E}-0) 1$ & $2.00 \mathrm{E}-01$ & $2.00 \mathrm{E}-01$ & j \\
\hline Fraction of wind from direction west & {$[-]$} & $1.60 \mathrm{E}-01$ & $1.60 \mathrm{E}-01$ & $1.60 \mathrm{E}-01$ & j \\
\hline Fraction of wind from direction north-west & {$[-]$} & $1.00 \mathrm{E}-01$ & $1.00 \mathrm{E}-01$ & $1.00 \mathrm{E}-01$ & $\mathrm{j}$ \\
\hline
\end{tabular}


Hydrobiologia (2006) 565:21-38

\begin{tabular}{|c|c|c|c|c|c|}
\hline Envirnmental parameter & Unit & $\begin{array}{l}\text { Value } \\
\text { upstream }\end{array}$ & $\begin{array}{l}\text { Value } \\
\text { midstream }\end{array}$ & $\begin{array}{l}\text { Value } \\
\text { downstream }\end{array}$ & Referenoc \\
\hline $\begin{array}{l}\text { Orientation of the up- with regard } \\
\text { to the midstream area }\end{array}$ & {$[-1$} & s & s & s & - \\
\hline $\begin{array}{l}\text { Orientation of the mid- with regard } \\
\text { to the downstream area }\end{array}$ & {$[\mathrm{H}$} & SE & $\mathrm{SE}$ & $\mathrm{SE}$ & - \\
\hline Rain intensity & {$\left[\mathrm{ms}^{-1}\right]$} & $1.10 \mathrm{E}+03$ & $8.23 \mathrm{E}+02$ & $9.21 \mathrm{E}+02$ & $k, v, j$ \\
\hline Infiltration fraction in floodph in soil & {$[-]$} & $8.50 \mathrm{E}-01$ & $9.00 \mathrm{E}-0) 1$ & $8.50 \mathrm{E}-01$ & c \\
\hline Infiltration fraction in catchment soil & {$[\mathrm{H}$} & $7.50 \mathrm{E}-01 \mathrm{l}$ & $8.50 \mathrm{E}-0.1$ & $8.50 \mathrm{E}-01$ & $\mathrm{e}$ \\
\hline Fraction of rainwater as sulkufface flow soil & {$[\mathrm{H}$} & $3.60 \mathrm{E}-0.2$ & $3.60 \mathrm{E}-02$ & $3.60 \mathrm{E}-0.02$ & - \\
\hline Fraction of rainwater as tube flow cropland soil & {$[-1$} & $2.50 \mathrm{E}-0) 1$ & $2.50 \mathrm{E}-0) 1$ & $2.50 \mathrm{E}-0.1$ & c \\
\hline Fraction of rainwater as tube flow pasture soil & {$[-]$} & $2.50 \mathrm{E}-01$ & $2.50 \mathrm{E}-01$ & $2.50 \mathrm{E}-01$ & $\mathrm{c}$ \\
\hline $\begin{array}{l}\text { Fraction of rainwater exported } \\
\text { to decp aquifers floodplain }\end{array}$ & {$[-]$} & $0.00 \mathrm{E}+(0)$ & $0.00 \mathrm{E}+\infty)$ & $0.00 \mathrm{E}+00$ & - \\
\hline $\begin{array}{l}\text { Fraction of rain water exportod } \\
\text { to deep aquifers catchment }\end{array}$ & {$[\mathrm{H}$} & $1.70 \mathrm{E}-0.1$ & $1.70 \mathrm{E}-0) 1$ & $1.70 \mathrm{E}-01$ & 1 \\
\hline $\begin{array}{l}\text { Fraction of soil water discharging } \\
\text { to primary waters }\end{array}$ & {$[\mathrm{H}$} & $5.00 \mathrm{E}-0) 1$ & $5.00 \mathrm{E}-0) 1$ & $5.00 \mathrm{E}-01$ & - \\
\hline $\begin{array}{l}\text { Fraction of soil water discharging } \\
\text { to socondary waters }\end{array}$ & {$[\mathrm{H}$} & $5.00 \mathrm{E}-0.1$ & $5.00 \mathrm{E}-0) 1$ & $5.00 \mathrm{E}-0) 1$ & - \\
\hline Temperature & {$\left[{ }^{\circ} \mathrm{C}\right]$} & $8.20 \mathrm{E}+(0)$ & $9.90 \mathrm{E}-(0)$ & $9.70 \mathrm{E}+00$ & $k, v, j$ \\
\hline Specific acrosol surface & {$\left[\mathrm{m}^{2} \mathrm{~m}^{-3}\right]$} & $1.50 \mathrm{E}-0.4$ & $1.50 \mathrm{E}-04$ & $1.50 \mathrm{E}-0.4$ & $\mathrm{~b}$ \\
\hline Mas fraction organic carbon in suspended matter & {$[-]$} & $2.00 \mathrm{E}-0) 1$ & 2.(0)E-0)1 & $2.00 \mathrm{E}-0.1$ & $\mathrm{~m}$ \\
\hline Fat content of fresh water fish & {$[-]$} & $5.00 \mathrm{E}-1) 2$ & $5.00 \mathrm{E}-102$ & $5.00 \mathrm{E}-0.12$ & b \\
\hline Concentration biota in fresh water & {$\left[\mathrm{mg}^{-1}\right]$} & $1.00 \mathrm{E}+00$ & $1.00 \mathrm{E}+(0)$ & $1.00 \mathrm{E}+00$ & $\mathrm{~b}$ \\
\hline $\begin{array}{l}\text { Conoentration suppended matter } \\
\text { in river water }\end{array}$ & {$\left[\mathrm{mg}^{-1}\right]$} & $1.50 \mathrm{E}+01$ & $2.90 \mathrm{E}+01$ & $3.50 \mathrm{E}+01$ & $n, w, y$ \\
\hline $\begin{array}{l}\text { Conoentration suspended matter } \\
\text { in primary waters }\end{array}$ & {$\left[\mathrm{mg} \mathrm{I}^{-1}\right]$} & $5.00 \mathrm{E}+00$ & $5.00 \mathrm{E}+00$ & $5.00 \mathrm{E}+00$ & - \\
\hline $\begin{array}{l}\text { Conoentration suspended matter } \\
\text { in secondary waters }\end{array}$ & {$\left[\mathrm{mg} \mathrm{I}^{-1}\right]$} & $1.50 \mathrm{E}+01$ & $2.90 \mathrm{E}+01$ & $3.50 \mathrm{E}+01$ & $\mathrm{n}, \mathrm{w}, \mathrm{y}$ \\
\hline Mas fraction organic carbon in sediment & {$[-]$} & $2.00 \mathrm{E}-0) 2$ & $2.00 \mathrm{E}-102$ & $2.00 \mathrm{E}-02$ & 0 \\
\hline Mas fraction organic carbon in unsaturated soil & {$[-]$} & $2.00 \mathrm{E}-0) 2$ & $2.00 \mathrm{E}-0.2$ & $2.00 \mathrm{E}-0.2$ & b \\
\hline Mas fraction organic carbon in saturated soil & {$[\mathrm{H}$} & $6.00 \mathrm{E}-0.3$ & $6.00 \mathrm{E}-0.3$ & $6.00 \mathrm{E}-0.3$ & 0 \\
\hline $\begin{array}{l}\text { Deposition velocity of acrosol } \\
\text { particks agricultural soil }\end{array}$ & {$\left[\mathrm{m} \mathrm{s}^{-1}\right]$} & $5.31 \mathrm{E}-0.4$ & $5.31 \mathrm{E}-0.4$ & $5.31 \mathrm{E}-04$ & $\mathrm{p}$ \\
\hline $\begin{array}{l}\text { Deposition velocity of acrosol } \\
\text { particles natural soil }\end{array}$ & {$\left[\mathrm{m} \mathrm{s}^{-1}\right]$} & $7.30 \mathrm{E}-0.3$ & $7.30 \mathrm{E}-0.3$ & $7.30 \mathrm{E}-0.3$ & $q$ \\
\hline Aerosol colloction efficiency & {$[\mathrm{H}$} & $2.00 \mathrm{E}+05$ & $2.00 \mathrm{E}+05$ & $2.00 \mathrm{E}+05$ & r \\
\hline Interoeption of dry acrosol deposition vegetation & {$[-]$} & $4.40 \mathrm{E}-0.1$ & $4.40 \mathrm{E}-0.1$ & $4.40 \mathrm{E}-01$ & 8 \\
\hline Interoeption of wet aerosol deposition vegetation & {$[-]$} & $1.40 \mathrm{E}-01$ & $1.40 \mathrm{E}-0,1$ & $1.40 \mathrm{E}-0.1$ & $\mathrm{t}$ \\
\hline Growth rate constant natural vegetation & {$\left[s^{-1}\right]$} & $2.88 \mathrm{E}-0.08$ & $2.88 \mathrm{E}-0.08$ & $2.88 \mathrm{E}-0.08$ & $\mathrm{i}$ \\
\hline Growth rate constant agricultural vegetation & {$\left[s^{-1}\right]$} & $1.27 \mathrm{E}-177$ & $1.27 \mathrm{E}-(1) 7$ & $1.27 \mathrm{E}-177$ & $\mathrm{i}$ \\
\hline Harvesting efficiency natural vegetation & {$[-]$} & $0.00 \mathrm{E}+00$ & $0.00 \mathrm{E}+00$ & $0.00 \mathrm{E}+00$ & b \\
\hline Harvesting efficiency agricultural vegetation & {$[-]$} & $5.90 \mathrm{E}-01$ & $5.90 \mathrm{E}-01$ & $5.90 \mathrm{E}-01$ & $\mathrm{~b}$ \\
\hline Water uptake rate natural vegetation & {$\left[\mathrm{ms}^{-1}\right]$} & $8.40 \mathrm{E}-099$ & $8.40 \mathrm{E}-109$ & $8.40 \mathrm{E}-099$ & $\mathrm{i}$ \\
\hline Water uptake rate agricultural vegetation & {$\left[\mathrm{ms}^{-1}\right]$} & $9.32 \mathrm{E}-(1) 9$ & $9.32 \mathrm{E}-109$ & $9.32 \mathrm{E}-109$ & $\mathrm{i}$ \\
\hline
\end{tabular}




\begin{tabular}{llllll}
\hline Environmental parameter & Unit & $\begin{array}{l}\text { Value } \\
\text { upstream }\end{array}$ & $\begin{array}{l}\text { Value } \\
\text { midstream }\end{array}$ & $\begin{array}{l}\text { Value } \\
\text { downstream }\end{array}$ & Reference \\
\hline $\begin{array}{l}\text { Settling velocity of suspended particles } \\
\text { Autochthonous production of suspended }\end{array}$ & {$\left[\mathrm{m} \mathrm{s}^{-1}\right]$} & $2.89 \mathrm{E}-05$ & $2.89 \mathrm{E}-05$ & $2.89 \mathrm{E}-05$ & $\mathrm{~b}$ \\
$\quad$ matter in water & {$\left[\mathrm{g} \mathrm{m}^{-2} \mathrm{y}^{-1}\right]$} & $1.00 \mathrm{E}+01$ & $1.00 \mathrm{E}+01$ & $1.00 \mathrm{E}+01$ & $\mathrm{~b}$ \\
Net sediment accumulation rate in water & {$\left[\mathrm{m} \mathrm{s}^{-1}\right]$} & $2.36 \mathrm{E}-11$ & $3.17 \mathrm{E}-11$ & $4.44 \mathrm{E}-11$ & $\mathrm{u}, \mathrm{x}, \mathrm{y}$ \\
Erosion in floodplain zone & {$\left[\mathrm{m} \mathrm{s}^{-1}\right]$} & $6.00 \mathrm{E}-02$ & $1.00 \mathrm{E}-02$ & $1.00 \mathrm{E}-04$ & $\mathrm{n}$ \\
Erosion in catchment zone & {$\left[\mathrm{m} \mathrm{s}^{-1}\right]$} & $9.00 \mathrm{E}-02$ & $3.00 \mathrm{E}-02$ & $1.00 \mathrm{E}-03$ & $\mathrm{n}$ \\
Escape rate constant of air to the stratosphere & {$\left[\mathrm{s}^{-1}\right]$} & $3.66 \mathrm{E}-10$ & $3.66 \mathrm{E}-10$ & $3.66 \mathrm{E}-10$ & $\mathrm{~b}$ \\
Regional OH-radical concentration & {$\left[\mathrm{cm}^{-3}\right]$} & $5.00 \mathrm{E}+05$ & $5.00 \mathrm{E}+05$ & $5.00 \mathrm{E}+05$ & $\mathrm{~b}$ \\
Mechanical reworking depth agricultural soils & {$[\mathrm{m}]$} & $2.00 \mathrm{E}-01$ & $2.00 \mathrm{E}-01$ & $2.00 \mathrm{E}-01$ & $\mathrm{~b}$ \\
Tube drainage depth & {$[\mathrm{m}]$} & $1.00 \mathrm{E}+00$ & $1.00 \mathrm{E}+00$ & $1.00 \mathrm{E}+00$ & $\mathrm{c}$ \\
Depth of transpiration flow pasture vegetation & {$[\mathrm{m}]$} & $2.00 \mathrm{E}-01$ & $2.00 \mathrm{E}-01$ & $2.00 \mathrm{E}-01$ & $\mathrm{z}$ \\
Depth of transpiration flow cropland vegetation & {$[\mathrm{m}]$} & $2.00 \mathrm{E}-01$ & $2.00 \mathrm{E}-01$ & $2.00 \mathrm{E}-01$ & $\mathrm{z}$ \\
Depth of transpiration flow natural vegetation & {$[\mathrm{m}]$} & $8.00 \mathrm{E}-01$ & $8.00 \mathrm{E}-01$ & $8.00 \mathrm{E}-01$ & $\mathrm{z}$ \\
Population density & {$\left[\mathrm{km}^{-2}\right]$} & $1.99 \mathrm{E}+02$ & $2.34 \mathrm{E}+02$ & $3.89 \mathrm{E}+02$ & a \\
Emission dose & {$\left[\mathrm{kg} \mathrm{km}^{-2}\right]$} & $3.17 \mathrm{E}+00$ & $2.60 \mathrm{E}+00$ & $8.27 \mathrm{E}+00$ & aa \\
\hline
\end{tabular}

Referenoes: $\mathrm{a}=$ Nationmaster (2005), $\mathrm{b}=$ Den Hollander \& Van de Meent (2004), c = McKone (1993), $\mathrm{d}=$ CLM (2004), $\mathrm{c}=$ Tiktak et al. (2002), $\mathrm{f}=$ Paterson \& Mackay (1994), $\mathrm{g}=$ Scurlock et al. (2001), $\mathrm{h}=$ Zeng et al. (2000), $\mathrm{i}=$ Severinsen \& Jager (1998), $\mathrm{j}=$ KNMI (2004), $\mathrm{k}=$ MeteoSchweiz (2004), 1 = De Wit (1999), $\mathrm{m}=$ Zhang et al. (2003), $\mathrm{n}=$ Asselman (1997), $o=$ McKone et al. (2001), $\mathrm{p}=$ McLachlan et al. (2002), q = Horsmann \& McLachlan (1998), $\mathrm{r}=$ Mackay (1991), $\mathrm{s}=$ Chamberla in (1967), $\mathrm{t}=$ Scheringer et al., (2000), $\mathrm{u}=$ Schwarzenbach et al. (1993), $\mathrm{v}=$ DWD (2004), $\mathrm{w}=$ Meybeck et al. (2003), $\mathrm{x}=$ Trapp (1996), $\mathrm{y}=$ Hofstoc \& Loenaers (2002), $\mathrm{z}=$ Jackson (1996), aa $=$ FAO (2001) $\mathrm{S}=$ South, $\mathrm{SE}=$ Southeas
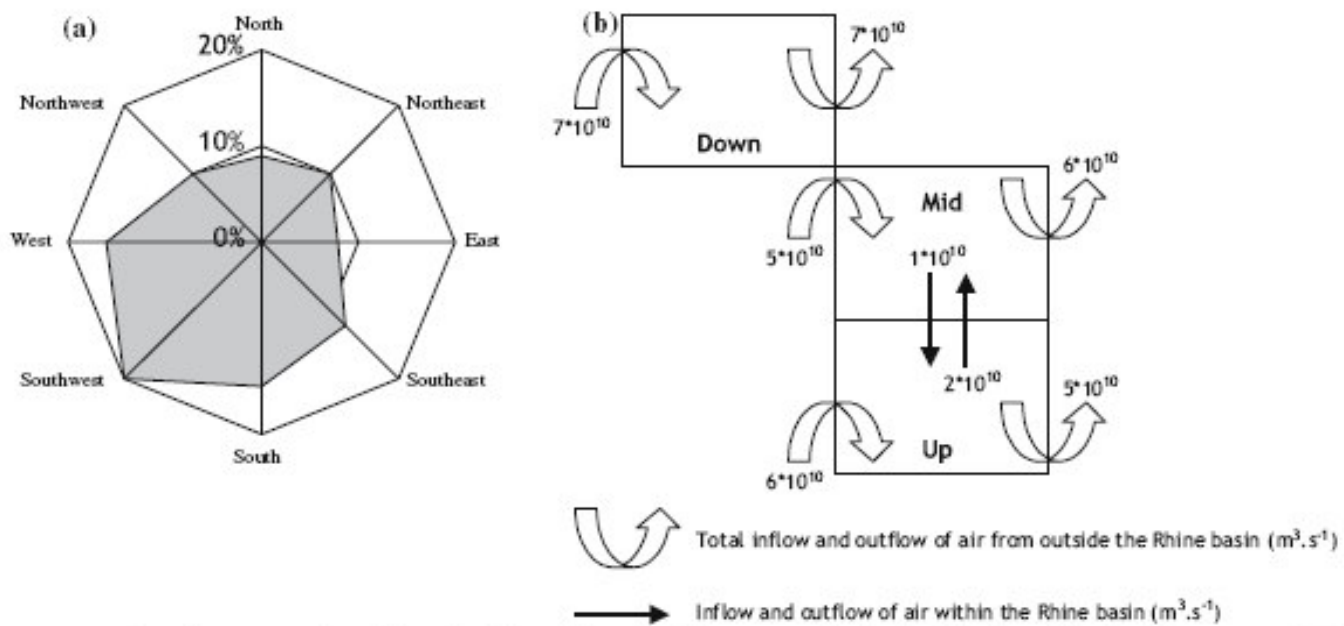

Figure 3. Schematic representation of the calculation of the chemical concentration in the inflowing air in the different areas of the river Rhine basin. (a) The percentage of each of the wind directions occurning in the river Rhine basin (KNMI, 20004). (b) Total amounts of inflowing and outflowing air in the different areas of the Rhine basin.

downstream areas as well as on differences in the typical pesticide emission dose between the different areas (Table 1). According to this method, the emission ratio between the upstream, midstream and downstream areas in the Rhine basin area is 1:2.6:6.3 for the floodplain soil compartment, and 1:1.9:4.5 for the catchment soil compartment (FAO, 2001; Nationmaster, 2005). Since we were interested in concentration differences between the upstream, midstream and downstream areas, rather than in absolute concentrations, only relative emission rates were required for the calculations.

\section{Concentration ratios}

For all hypothetical chemicals, the concentration ratio between the upstream area and the downstream area was calculated for each emission scenario and for all compartment types. These results were analysed in order to select all 
combinations of chemical properties for which the concentration ratio between the downstream and upstream areas is larger than 100, respectively 10 or smaller than 0.01 , respectively 0.1 . This was done to select those chemicals for which predicting concentrations within the river Rhine area for the upstream, midstream and downstream area separately can be relevant. For all combinations of emission scenario and compartment type at which concentration ratios $>100$ or $<0.01$ occur, series of chemical space plots were created. In these chemical space plots, the concentration ratio between downstream and upstream areas is plotted against Kow and Kaw for a certain value of the chemical degradation half-lives in air and water (and soil). Since the calculations were performed for five values of the degradation half-life in water and five values of the degradation half-life in air, for each combination of emission scenario and compartment 25 plots can be made. It appeared that the degradation rate of compounds in air hardly influenced the concentration ratios in our calculations, so plots were created for only one value of the degradation half-life in air. We used the median of the modeled values of the half-life in air $(168 \mathrm{~h})$. The plots provide a clear overview of chemical property combinations causing large spatial variation in the predictions of BasinBox.

\section{Results and discussion}

Table 2 shows for all combinations of emission scenario and compartment type the percentage of hypothetical chemicals for which the predicted concentrations of BasinBox in the upstream and downstream areas differ more than a factor of 10 and 100 , respectively. In more than $95 \%$ of all cases, downstream concentrations are higher than upstream concentrations, implying that there is a clear trend of increasing chemical concentrations in downstream direction of the Rhine basin area. This is mainly caused by differences in emissions between the upstream and downstream area. Since the upstream area of the Rhine basin is less densely populated and contains less agricultural soils, emissions to air, river water as well as cropland soils are lower than in the downstream area.

Furthermore, water based transport of chemicals, which occurs in downward direction of the river basin, causes variation in chemical concentrations between the upstream and downstream areas. For the river and floodplain compartments, the influence of downward transport can account for up to $60 \%$ of the concentration variance between the upstream and downstream areas, particularly when emissions occur to water. For the catchment compartments this downward chemical transport is only of minor influence.

For 13 combinations of emission scenario and compartment type concentration ratios $>100$ appeared. For all these scenarios, series of chemical space plots were created, consisting of five separate plots for all five modelled values of the degradation half-life in water (and soil). Two series of chemical space plots are given in Figure 4, while the full set of plots (in colour) can be downloaded from http://www.ru.nl/environmentalscienceresearch/rivers/basinbox.

\section{River water emission scenario}

In case of emissions towards river water, relatively large spatial differences (ratio $>100$ ) are found for about 60 chemical property combinations in cropland soils and pasture soils in the floodplain. Figure $4 a$ shows the chemical space plots for the cropland soil compartment in the floodplain. The main transport routes responsible for the concentration differences are (1) downward transport of chemicals by river water and (2) temporal inundation of downstream floodplain soils and subsequent sedimentation of chemicals onto these soils. Beside that, variations in emission densities between the upstream and downstream areas 
account for concentration differences. For the natural soil compartments in the floodplain, concentration ratios are somewhat lower, but still larger than 10 for $8.5 \%$ of the chemicals. As a result of high concentration ratios in the floodplain soils, also the saturated soil zone in the floodplain shows concentration ratios $>10$ for some compounds.

In floodplain pasture and cropland soils, chemical property combinations for which the concentration ratio is larger than 100 range between a log Kaw of 0 to 2 with a log Kow of 8 . These chemicals have a high volatilisation potential from water to air on the one hand, and tend to bind to organic material on the other hand. So, when sedimentation in the floodplain occurs, a large part of these chemicals will settle down to the floodplain soils. Only compounds with a relatively high half-life in water ( 8760 to $87,600 \mathrm{~h}$ ) and soil $(17,520$ to $175,200 \mathrm{~h}$ ) will show relatively large concentration differences between the upstream and the downstream areas.

The degradation halflife of chemicals in air does not largely influence the fate of chemicals. Not many chemicals exist for which the above-mentioned property combinations apply, but octachloro)2-pinene (cas \# 25267- 15-6; pesticide; PAN, 2005) and 1-iodohexadecane (cas \# 544-77-4; pesticide; PAN, 2005) are known compounds in this range. For cropland soils in floodplains, the same applies as for pasture soils, but the range of chemicals for which large concentration ratios occur is somewhat broader. Chemicals with a log Kaw of )7, a log Kow of 8 and a water degradation half-life of $8760 \mathrm{~h}$, as well as chemicals with a log Kaw of )5, a log Kow of 7 and a water degradation half-life of $24 \mathrm{~h}$ show concentration ratios $>100$. Examples of chemicals that have the above-mentioned chemical property combinations are monomethyl ester (cas \# 6983- 79-5; pesticide; PAN, 2005) and isodecyl-diphenyl phosphate (cas \# 29761-21-5; plasticizer/flame retardant; Chemicalland21, 2005), respectively. Cropland soil emission scenario For the emission scenario to cropland soils, 11 compartment types show a concentration ratio between the downstream and upstream areas larger than 100 for a number of hypothetical chemicals

This is the case for the air compartment, all soil and vegetation compartments in the floodplain zone, pasture soils and natural soils in the catchment zone and pasture, cropland and natural vegetation in the catchment zone. The large ratios are mainly caused by differences in emission densities, followed by differences in the volatilization of chemicals from soil and vegetation to the air. In the saturated soil and in primary waters, concentration differences larger than a factor of 10 occur.

These differences are a direct consequence of concentration differences in the soil compartments, which results in different chemical amounts leaching to the saturated soil zone and draining to the surface water compartments. The series of chemical space plots for the natural soil compartment in the catchment for the soil emission scenario is shown in Figure $4 b$, but this situation applies approximately for all compartments with emissions to soils and concentration ratios $>100$. Chemicals with a log Kaw ranging from ) 6 to ) 3 and a log Kow from 5 or $6-8$ show the largest concentration ratios. These compounds tend to bind to organic material on the one hand and are not very volatile on the other hand.

Large concentration ratios are only found for chemicals with degradation half-lives in water of 24 or $168 \mathrm{~h}$. This is caused by differences in the soil penetration depth of the chemicals, which is low for compounds with low degradation half-lives in water and soil. As a result, the process of volatilization becomes relatively important for those compounds, so in case of emissions taking place to the cropland soil compartments, the differences in emission densities between the upstream and downstream areas are being strengthened by this volatilisation flow. Therefore, large concentration differences arise in the upstream and 
downstream areas. In cropland soils their selves, the concentration ratio is not so large, since for those compartments the emission process is much more important than the volatilisation flow. Consequently, the concentration ratio in the cropland soil compartments equals more or less the soil emission ratio. As is the case by emissions to river water, the degradation half-life of chemicals in air does hardly influence their fate. Examples of real chemicals having the property combinations that result in large concentration differences between the upstream and downstream areas are tributyltin adipate (cas \# 7437-35-6; pesticide; PAN, 2005), oleic acid (cas \# 112-80-1; high production volume chemical, used in consumer products, building materials and pesticides; Scorecard, 2005), dicyclohexyl phtalate (cas \# 84-61-7; high production volume chemical, used as plasticizer; Scorecard, 2005), and tetradecanol (cas \# 112-72- 1; high production volume chemical, used in consumer products, building materials and pesticides; Scorecard, 2005).

\section{Air emission scenario}

In case of emissions occurring towards the air compartments, none of the compartment types shows a concentration ratio between the upstream and downstream areas larger than 100, and only a few compartment types show a ratio larger than 10 . Due to rapid mixing of chemicals in the atmosphere and because air-based chemical transport takes place both in upstream and in downstream directions, the concentration differences between the downstream area and the upstream area remain relatively low.

\section{Uncertainty}

From these calculations it becomes clear, that for certain types of chemicals large concentration differences can exist within one river basin. One remark should be made on the model results for the compounds with low degradation half-lives in air, water and soil and with a high Kow (half-life in water of 24 h, log Kow from 7 to 8). Although these compounds have a low soil penetration depth in reality, predicted soil penetration depths are even considerably lower. The algorithm of the soil penetration depth in BasinBox was primarily designed for compounds with less extreme property combinations, and it is not possible to extrapolate it directly to all chemicals. Therefore, the concept of the soil penetration depth in BasinBox does not apply very well on extreme hydrophobic and rapidly degrading compounds. Since the soil penetration depth largely influences the concentration ratios, especially when emissions take place to the soil, for these compounds the model results are not very reliable. However, for the other compounds the model relations do apply and compounds showing large concentration ratios still exist.

The relevance of the BasinBox model not only depends on relative differences that are found between the upstream, midstream and downstream areas of a river basin, but also on the absolute concentration differences. When concentration differences are large, but absolute chemical concentrations are very low, knowledge about the concentration differences is not very relevant. Since the example calculations were based on relative emissions, the model predicts only relative concentrations. To get an idea about absolute concentrations anyhow, we compared the relative concentrations in cropland soils and in natural soils after emission of chemicals to cropland soils.

We assumed that if natural soil concentrations are less than six orders of magnitude lower than cropland soil concentrations (after cropland soil emission), these concentrations might be of serious concern. This appeared to be the case for $89 \%$ of the hypothetical chemicals, and for $76 \%$ of the chemicals that show concentration ratios $>100$ between downstream and upstream areas. For $10 \%$ of 
all chemicals the natural soil concentrations are even less than three orders of magnitude lower than cropland concentrations. These numbers indicate that for a large number of chemicals relevant concentrations may be found, in any case in natural soils. For these chemicals also knowledge about concentration variances will be relevant. Although it is quite difficult to validate this type of generic models with such a large amount of compartments, a validation study has to be carried out to judge whether the spatial variation in predicted concentrations in BasinBox agrees with actual concentration differences throughout a river basin. In a next step in research we will perform a validation study for the BasinBox model using real chemical data in different river catchments, based on real emission scenarios.

\section{Conclusion}

BasinBox is a new generic multimedia fate model that predicts environmental concentrations of chemicals in large river basins. It distinguishes an upstream, midstream, and downstream area with different environmental characteristics. Water transport is modelled in a downward direction, and floodplain inundations are taken into account. It appears that BasinBox predicts significant concentration differences between upstream and downstream areas of the river Rhine basin for different types of chemicals and different emission scenarios. There is a clear trend of increasing chemical concentrations in the downstream direction of the river basin. This case study shows that taking into account spatial variability between upstream, midstream and downstream areas of large river basins can be important in the predictions of environmental concentrations by multimedia fate models. 


\section{References}

Asselman, N. E. M., 1997. Suspended Sediment in the River Rhine. The Impact of Climate Change on Erosion, Transport and Deposition. PhD-thesis, Department of Physical Geography, Utrecht University, Utrecht.

Baughman, G. L. \& R. R. Lassiter, 1978. Prediction of environmental pollutant concentration. In Cairns, J., D. L. Dickson \& A.W. Maki (eds), Estimating the Hazard of Chemical Substances to Aquatic Life. American Society for Testing Materials (ASTM) 657: 34-54.

Boorman, D. B., 2003. LOIS in-stream water quality modelling. Part 1: catchments and methods. Science of the Total Environment 314: 379-395.

Brandes, L. J., H. den Hollander \& D. van de Meent, 1996. SimpleBox 2.0: A Nested Multimedia Fate Model for Evaluating the Environmental Fate of Chemicals. RIVM, Bilthoven.

Briggs, C. G., R. H. Bromilov \& A. A. Evans, 1982. Relationships between lipophilicity and root uptake and translocation of non-ionised chemicals by barley. Pesticide Science 13: 495-504.

Cahill, T. M. \& D. Mackay, 2003. A high-resolution model for estimating the environmental fate of multi-species chemicals: application to malathion and pentachlorophenol. Chemosphere 53: 571-581.

Chamberlain, A.C., 1967. Transport of lycopodium spores and other small particles to rough surfaces. Proceedings of the Royal Society of London A296: 45-70.

Centrum voor Landbouw en Milieu (CLM), 2004. Werken aan duurzame landbouw en een aantrekkelijk platteland. www.clm.nl (in Dutch).

Chemicalland21, 2005. www.chemicalland21.com.

Commonwealth Scientific and Industrial Research Organization (CSIRO), 1994. CSIRO sustainable ecosystems - Software and resources. http://www.cse.csiro.au/poptools/.

Coulibaly, L., M. E. Labib \& R. Hazen, 2004. A GIS-based multimedia watershed model: development and application. Chemosphere 55: 1067-1080.

Cousins, I. T. \& D. Mackay, 2001. Strategies for including vegetation compartments in multimedia models. Chemosphere 44: 643-654.

De Nooij, R. J. W., W. C. E. P. Verberk, H. J. R. Lenders, R. S. E. W. Leuven \& P. H. Nienhuis, 2006. The importance of hydrodynamics for protected and endangered biodiversity of lowland rivers. Hydrobiologia 565: 153-162.

De Wit, M. J. M., 1999. Nutrient fluxes in the Rhine and Elbe basins. Ph.D. thesis. Department of Physical Geography, Utrecht University, Utrecht.

Den Hollander, H. \& D. van de Meent, 2004. SimpleBox 3.0: A Multimedia Fate Model for Evaluating Environmental Behaviour of Chemicals. RIVM, Bilthoven.

Diamond, M. L., D. A. Priemer \& N. L. Law, 2001. Developing a multimedia model of chemical dynamics in an urban area. Chemosphere 44: 1655-1667.

DiToro, D. M., C. S. Zarba, D. J. Hansen, W. J. Berry, R. C. Swartz, C. E. Cowan, S. P. Pavlou, H. E. Allen, N. A. Thomas \& P. R. Paquin, 1991. Technical basis for establishing sediment quality criteria for 
nonionic organicchemicals using equilibrium partitioning. Environmental Toxicology and Chemistry 10: 1541-1583.

Deutscher Wetterdienst (DWD), 2004. www.dwd.de.

EC, 2000. Water Framework Directive. European Commission, Brussels.

ECB, 2003. Technical Guidance Document on Risk Assessment. JRC-Ispra, Italy.

ECNC, 2004. European Centre for Nature Conservation. http://www.ecnc.nl/.

FAO, 2001. Food and Agriculture Organization of the United Nations. http://faostat.fao.org/.

Feijtel, T., G. Boeije, M. Matthies, A. Young, G. Morris, C. Gandolfi, B. Hansen, K. Fox, M. Holt, V. Koch, R. Schroder, G. Cassani, D. Schowanek, J. Rosenblom \& H. Niessen, 1997. Development of a geography-referenced regional exposure assessment tool for European rivers - GREAT-ER contribution to GREAT-ER \#1. Chemosphere 34: 2351-2373.

Fenner, K., M. Scheringer \& K. Hungerbu“ hler, 2000. Persistence of parent compounds and transformation products in a level IV multimedia model. Environmental Science and Technology 34: 3809-3817.

Fenner, K., M. Scheringer, M. MacLeod, M. Matthies, T. McKone, M. Stroebe, A. Beyer, M. Bonnell, A. C. Le Gall, J. Klasmeier, D. Mackay, D. van de Meent, D. Pennington, B. Scharenberg, N. Suzuki \& F. Wania, 2005. Comparing estimates of persistence and long-range transport potential among multimedia models. Environmental Science and Technology 39: 1932-1942.

Hofstee, C. \& H. Leenaers, 2002. Actief beheer van de waterbodem in landelijk perspectief. TNO-NITG, Utrecht (in Dutch).

Hollander, A., L. K. Hessels, P. de Voogt \& D. van de Meent, 2004. Implementation of depthdependent soil concentrations in multimedia mass balance models. SAR and QSAR in Environmental Research 15: 457-468.

Horstmann, M. \& M. S. McLachlan, 1998. Atmospheric deposition of semivolatile organic compounds to two forest canopies. Atmospheric Environment 32: 1799-1809.

Jackson, R., 1996. A global analysis of root distributions for terrestrial biomes. Oecologia 108: 389411. Junge, C. E., 1977. Basic considerations about trace constituent in the atmosphere related to the fate of global pollutants. In Suffet, I. H. (ed.), Fate of Pollutants in the Air and Water Environment. Wiley-Interscience: 7-25.

Koninklijk Nederlands Meteorologisch Instituut (KNMI), 2004. Klimaat en klimaatverandering: klimatologische informatie. www.knmi.nl/voorl/weer/ (in Dutch).

Mackay, D., 1991. Multimedia Environmental Models. Lewis, Chelsea.

Mackay, D. \& S. Paterson, 1981. Calculating fugacity. Environmental Science and Technology 15: 1006-1014.

Mackay, D., S. Paterson \& M. Joy, 1983. Application of fugacity models to the estimation of chemicaldistribution and persistence in the environment. ACS Symposium Series 225: 175-196.

McKone, T. E., 1993. CalTOX, A Multimedia Total-exposure Model for Hazardous-wastes Sites. Part 1: Executive Summary. Lawrence Livermore National Laboratory, Livermore. 
McKone, T. E. \& D. H. Bennett, 2003. Chemical-specific representation of air-soil exchange and soil penetration in regional multimedia models. Environmental Science and Technology 37: 3123-3132.

McKone, T. E., A. B. Bodnar \& E. G. Hertwich, 2001. Development and Evaluation of State-specific Landscape Data Sets for Multimedia Source-to-dose Models. School of Public Health, University of California, Berkeley.

McLachlan, M. S., G. Czub \& F. Wania, 2002. The influence of vertical sorbed phase transport on the fate of organic chemicals in surface soils. Environmental Science and Technology 36: 4860-4867.

MeteoSchweiz, 2004. www.meteoschweiz.ch.

Meybeck, M., L. Laroche, H. H. Durr \& J. P. M. Syvitski, 2003. Global variability of daily total suspended solids and their fluxes in rivers. Global and Planetary Change 39: 65-93.

Nationmaster, 2005. http://www.nationmaster.com.

Nienhuis, P. H., A. D. Buijse, R. S. E. W. Leuven, A. J. M. Smits, R. J. W. de Nooij \& E. M. Samborska, 2002. Ecological rehabilitation of the lowland basin of the river Rhine (NW Europe). Hydrobiologia 478: $53-72$.

PAN, 2005. Pesticides database. http://www.pesticideinfo.org/ List_ChemicalsAlpha.jsp.

Paterson, S. \& D. Mackay, 1994. Interpreting chemical partitioning in a soil-plant-air system with a fugacity model. In Trapp, S. \& C. McFarlane (eds), Plant Contamination, Modeling and Simulation of Organic Chemical Processes. Lewis Publishers/CRC Press: 191-214.

Prevedouros, K., K. C. Jones \& A. J. Sweetman, 2004. European- scale modeling of concentrations and distribution of polybrominated diphenyl ethers in the pentabromodiphenyl ether product. Environmental Science and Technology 38: 5993-6001.

Scheringer, M., F. Wegmann, K. Fenner \& K. Hungerbuhler, 2000. Investigation of the cold condensation of persistent organic pollutants with a global multimedia fate model. Environmental Science and Technology 34: 1842-1850. Schumm, S. A., 1977. The Fluvial System. WileyInterscience, New York.

Schwarzenbach, R. P., P. M. Gschwend \& D. M. Imboden, 1993. Environmental Organic Chemistry. John Wiley \& Sons, New York.

Scorecard, 2005. The pollution information site. www.scorecard.org.

Scurlock, J. M. O., G. P. Asner \& S. T. Gower, 2001. Worldwide Historical Estimates of Leaf Area Index, 1932-2000. Oak Ridge National Laboratory, Oak Ridge.

Severinsen, M. \& T. Jager, 1998. Modelling the influence of terrestrial vegetation on the environmental fate of xenobiotics. Chemosphere 37: 41-62.

Stroebe, M., M. Scheringer \& K. Hungerbu" hler, 2004. Measures of overall persistence and the temporal remote state. Environmental Science and Technology 38: 5665-5673.

Suzuki, N., K. Murasawa, T. Sakurai, K. Nansai, K. Matsuhashi, Y. Moriguchi, K. Tanabe, O. Nakasugi \& M. Morita, 2004. Geo-referenced multimedia environmental fate model (G-CIEMS): model formulation and comparison to the generic model and monitoring approaches. Environmental Science and Technology 38: 5682-5693. 
Tiktak, A., D. de Nie, T. van der Linden \& R. Kruijne, 2002. Modelling the leaching and drainage of pesticides in the Netherlands: theGeoPEARLmodel.Agronomie 22: 373-387.

Toose, L., D. G. Woodfine, M. MacLeod, D. Mackay \& J. Gouin, 2004. BETR-World: a geographically explicit model of chemical fate: application to transport of alpha- $\mathrm{HCH}$ to the Arctic. Environmental Pollution 128: 223-240.

Trapp, S., 1996. Querprofile, WQ-, QW-, WB- und Wu-Regressionen, Einleiterstandorte für den Rhein. Universität Osnabrück, Institut f"rr Umweltsystemforschung, Osnabrück.

Trapp, S. \& M. Matthies, 1996. Generic one compartment model for uptake of organic chemicals by foliar vegetation. Environmental Science and Technology 30: 360.

US-EPA., 2002. TRIM.FaTE Technical Support Document. Volume 1: Description of Module. USEnvironmental Protection Agency, North Carolina.

Vermeire, T. G., D. T. Jager, B. Bussian, J. Devillers, K. den Haan, B. Hansen, I. Lundberg, H. Niessen, S. Robertson, H. Tyle \& P. T. J. van der Zandt, 1997. European Union System for the Evaluation of Substances (EUSES). Principles and structure. Chemosphere 34: 1823-1836.

Vermeire, T., M. Rikken, L. Attias, P. Boccardi, G. Boeije, D. Brooke, J. de Bruijn, M. Comber, B. Dolan, S. Fischer, G. Heinemeyer, V. Koch, J. Lijzen, B. Mu“ Iler, R. Murray- Smith \& J. Tadeo, 2005. European union system for the evaluation of substances: the second version. Chemosphere 59: 473485.

Webster, E., D. Mackay, A. Di Guardo, D. Kane \& D. Woodfine, 2004. Regional differences in chemical fate model outcome. Chemosphere 55: 1361-1376.

Woodfine, D. G., M. MacLeod, D. Mackay \& J. R. Brimacombe, 2001. Development of continental scale multimedia contaminant fate models: integrating GIS. Environmental Science and Pollution Research 8: 164-172.

Zeng, X. B., R. E. Dickinson, A. Walker, M. Shaikh, R. S. DeFries \& J. G. Qi, 2000. Derivation and evaluation of global $1-\mathrm{km}$ fractional vegetation cover data for land modeling. Journal of Applied Meteorology 39: 826-839.

Zhang, Q. O., J. C. Crittenden, D. Shonnard \& J. R. Mihelcic, 2003. Development and evaluation of an environmental multimedia fate model CHEMGL for the Great Lakes region. Chemosphere 50: 13771397. 